\title{
The uncertainties of climate change in Spanish daily newspapers: content analysis of press coverage from 2000 to 2010
}

\section{Emilia Lopera and Carolina Moreno}

\begin{abstract}
This paper explores media coverage of climate science through a selection of Spanish newspapers (El País, El Mundo, ABC, Expansión and Levante). We selected a stratified random sample of 363 items to be studied for eleven years (2000-2010). Content analysis allowed us to find out media attention paid to climate science, prevalence of informative tables, evaluation and characterization of news, as well as the presence of questioning or rejection of climate change. According to main results, press coverage of climate science in Spain was mainly focused on the consequences rather than on the causes or natural sources, and media attention paid to it was limited. Overlapping with social and macroeconomic problems in the country also contributed to communication of climate science as a controversial and uncertain science through informative framings.
\end{abstract}

KEYWORDS: Environment communication, science and media, climate change science

\section{Introduction $^{1}$}

Spain is one of the European countries most vulnerable to the impact of climate change, due to its geographical location [1] However, even if political action both by governments or individual citizens can be either favoured or blocked depending on media position, the role of media in analysing and/or disseminating such a controversial topic has been scant. On the contrary, other European countries, e.g. the U.K. [2-4], Portugal [5], France [6, 7], or Germany $[8,9]$, have been studying for more than a decade how media deal with the problem of climate change and how different reporting practices influence its perception in public opinion.

Nevertheless, in recent years, Spanish speaking countries - Argentina [10], Mexico [11, 12], Perú [13], and Spain [14] — have shown a certain interest in this line of

\footnotetext{
${ }^{1}$ This article is the result of an ongoing research financially supported by two projects approved by the Spanish Ministry of Economy and Competitiveness: Politics of scientific culture: Analysis of the politic and social dimensions of scientific culture (FF12011- 24582) and Analysis of institutional campaigns on Human Papillomavirus vaccination (CSO2011-25810).
} 
research. This paper aims to contribute to this field of research by scrutinizing the journalistic production on climate science from 2000 to 2010, at a group of selected national newspapers: El País, El Mundo, and $A B C$, as well as Levante, a regional journal, and Expansión, a business and economic daily.

This paper also falls in line with research on public understanding of science, which takes into account not only the so-called cognitive deficits but also the factors that influence social appropriation of such knowledge. As the literature shows, scientific knowledge is usually incorporated within objects and services as well as individuals through their skills and qualifications, within institutions through their operational capabilities, ultimately becoming a part of culture, values, and personal attitudes [15] In any case, before scientific knowledge can be apprehended, it must be transmitted.

The analysis of climate science media coverage is based upon three needs: a) apart from formal education, media are the main source of climate change information for the lay public [16], b) this phenomenon has a number of features that act as barriers that hinder public cognitive understanding [17] and attenuate the perception of risk, and c) global climate policies are negotiated on the basis of scientific information on the issue. Therefore, the manner in which media report this particular science is of crucial importance.

The combination of features that make climate change a singular environmental problem stems from its considerable scientific complexity [9], as well as from the fact that it is so closely related to the current energy systems that articulate economic and social development. In addition, climate risk perception is tempered by different factors. First, both its causes and consequences make it a global phenomenon, although its impact has an irregular geographical distribution $[1,2,18]$. Second, many ecological crises of global reach, such as biodiversity problems or climate change, are so abstract that they escape direct public awareness [19] To these facts must be added the lack of direct experience, as cause and effect are not obvious. Finally, the most serious consequences are perceived as something distant in both time and space due to environmental hyperopia [20], a strategy that relieves people of any personal responsibility.

Based upon the theoretical attention-cycle model to environmental problems developed by Anthony Downs [21], this paper has analysed the evolution in the volume of media coverage on climate science in the Spanish newspapers, taking as a reference the state of the question in the international arena after twenty years of development in this line of research. General framings of data were analysed according to the categorization made by Entman in 1993 [22], partially replicating the work done in the U.S. [23, 24], that is the specific framings of climate science [25], and the causes, consequences and solutions of the phenomenon - as well as the spatial and temporal scales in which consequences are positioned - were characterised.

According to the framing analysis tradition, informative frames in media coverage provide a "scheme of interpretation" that gives meaning to an event by selecting and highlighting certain aspects of reality in order to promote a particular evaluation and solution [22]. This scheme of interpretation is more relevant when journalists report complex issues that have not been directly experienced [26]. 
This paper contributes to the existing research on framing analysis by developing an in-depth and systematic characterization and assessment of the general framing categories and subcategories. Compared with other studies that examined the framing used in climate science communication, here we tried to go a step further by combining the analysis of general framings with the analysis of specific framings of climate science, in addition to coding the problem recognition and the arguments used by journalists to deny or question the phenomenon of climate change. We argue that this approach can be a useful research tool to better understand how complex and controversial scientific issues such as climate change are translated and shaped by newspapers.

In a broader research context, the relevance of this type of studies is based on the role that media plays both in public perception of climate risk and in political action when designing mitigation and adaptation measures. Ultimately, the implementation of these measures at global level will determine how humanity is going to cope with extreme weather conditions for the years and decades to come.

\section{Questions selected for investigation}

Q1. How has media coverage of climate science in the Spanish written press evolved from 2000 to 2010 ?

Q2. What were the most frequent informative framings in the analysed period?

Q3. How did Spanish newspapers construct (a) the causes, (b) consequences and (c) solutions of climate change?

Q4. What (a) spatial and (b) temporal scales of climate change consequences were offered by the newspapers we analysed?

Q5. Could the Spanish press contribute to the creation of scientific uncertainty about climate change?

\section{Social communication regarding climate change in Spain}

The first studies of media coverage on climate change in Spain appeared in 2007. The first analysed a possible direct connection between the public figure Al Gore and the onset of climate change reports in the three leading national general newspapers [27] Assuming that media are often the primary source of information for people, a second paper addressed the social construction of climate change in Al Gore's documentary "An Inconvenient Truth" [28]. The collective representation of desolate landscapes provided by climate disaster movies over at least the past thirty five years was also the subject of study [29]. Their powerful images of desolation and death may have influenced the dramatization of journalistic information about climate change [30, 31]. One example is provided by an interview published in El Mundo [32], illustrated with an image from a 
climate disaster fiction film showing a flooded New York City with sea level reaching the breast of the Statue of Liberty. ${ }^{2}$

In 2009 a Ph.D. thesis on the treatment of climate change by editorials published in Libertad Digital, El Mundo, El País, and El Ecologista from 1992 to 2008 [33] was presented at Pablo Olavide University, in Seville, Spain. This research was approached from the perspectives of political ecology and environmental reporting in order to analyse different ideological positions on climate change. Finally, the Infoamérica-ICR journal, linked to the UNESCO Chair in Communication at Málaga University, published a special issue on climate change and communication in 2009 [34]. This monograph included both articles in Spanish - in order to introduce international reference works to the Spanish-speaking community — as well as in English, to provide external visibility to Latin American papers. In 2012 a monograph was published addressing media discourse on climate change. In particular, one of its chapters focused on analysing Spanish television coverage of climate summits in Cancun and Durban [14].

\section{Theoretical framework}

This research uses the attention-cycle model regarding environmental problems [21] to explain why the amount of information on climate science shows a cyclical pattern. According to this model, social concern for specific environmental problems does not depend on the objective severity of each problem but on the level of media attention devoted, based upon public interest in the topic. The results from these papers have been interpreted from this theoretical perspective [23, 24, 35].

The application of framing analysis to the study of media coverage of climate science in Spain stems from Goffman's general definition of this construct in the 70s [36]. He defined "frame" from a sociological perspective as a "scheme of interpretation" articulated from a number of internal and external signals that give meaning to an event and help both to interpret and understand it. Entman's concept of informative framing serves to illustrate the power of written communication [37]. It consists of selecting and highlighting certain facets of an issue and relating them in ways that promote a particular interpretation, evaluation and/or solution [37, 38]. The analysis of informative framings is paramount to understanding how media present certain questions to society [39]. Ultimately, the selection of certain "frames" tends to highlight specific aspects of a problem over others, that will be well received and understood as such by the public [22, 37, 40].

The political relevance of information framings lies in that the way societies perceive and understand specific problems and in turn will determine whether they believe the problem must be dealt with and what is the best way to do it. Many papers that focus on environmental issues and climate change have been written under this theoretical frame-

\footnotetext{
${ }^{2}$ El Mundo (January 9, 2006) published an interview with well-known scientist James Lovelock framing the story news to highlight dramatic aspect of climate change. This drama frame was constructed using a shot of the film "The Day After Tomorrow" as the main picture and with the headline "The non-stop climate catastrophe".
} 
work [13, 24, 25, 35, 39, 41-45]. Back in 1993 Entman argued that "frames" define problems, diagnose causes, convey moral judgments and propose solutions [22]. Therefore, the general information framings categories used in this study were precisely causes, consequences and solutions, as well as a framing of responsibility. Also, in order to determine the role played by daily newspapers in the creation of scientific uncertainty about climate change we also performed an analysis of specific information framings of climate science following the taxonomy outlined by Antilla in the U.S. in 2005 [25].

\section{Method}

We selected the three leading Spanish general information newspapers according to Spain's Bureau of Broadcast Measurement: El País, El Mundo, and ABC [46], the leading national business and financial daily Expansión and Levante, one of the most widely circulated newspapers in the Eastern region of Spain, containing the most kilometres of coastline. These papers cover most of the political spectrum and the sum of their circulation figures fluctuate at around one million copies per day [46].

The choice of these media was based on the fact that most of the papers which had previously analysed media portrayal of climate change and its science used written press as a reference $[4,9,23-25,47]$. Media debate on climate change in other communication outlets was either extremely limited or nonexistent [4]. In addition, the written press media coverage enriched this analysis by including political, economic, energy and environmental aspects of climatic change [48].

The time frame for this research was eleven years, from 2000 to 2010, because according to previous studies [49, 50], in 2000 the Spanish daily press began publishing a greater volume of news on climate change. It was during this period that the last two assessment reports on climate change by the UN Intergovernmental Panel on Climate Change (IPCC) were published, while controversies and disputes about the reliability of the work of the members of this group of experts arose, such as the scandal known as Climategate $^{3}$ or the erroneous statement that Himalayan glaciers would disappear in 2035. Finally, after the 2009 Copenhagen Summit, these eleven years served to make perfectly clear the difficulties of reaching a comprehensive, binding and effective political agreement on reducing emissions.

The analytical corpus was formed with 363 pieces of information selected by stratified systematic random sampling from a population of 1,810 units of analysis. The population was obtained by Boolean keyword searches in the Mynews.com database, following the example of other works done with British and American press [4, 23-25, 47]. Among the search criteria used, there was a keyword series - greenhouse effect or global warming or

\footnotetext{
${ }^{3}$ Due to a supposed analogy with the Watergate political scandal, Climagate was the term selected by the English-language media for the public and anonymous dissemination of numerous emails between a group of climatologists from the Climatic Research Unit of the University of East Anglia, in the U.K., that were pirated from computers servers. These events took place in November 2009, a few weeks before the start of the Copenhagen Climate Summit.
} 
Table 1. Numerical values assigned to the categories of the variable for dedicated reporting space.

\begin{tabular}{|c|c|}
\hline \multicolumn{2}{|c|}{ Encoding of the information space dedicated } \\
\hline Pages & Numerical value \\
\hline More than $3 / 4$ & 1 \\
\hline More than $1 / 2$ & 0.6 \\
\hline More than $1 / 4$ & 0.3 \\
\hline More than $1 / 8$ & 0.2 \\
\hline Less than $1 / 8$ & 0.1 \\
\hline
\end{tabular}

climate or IPCC or snowmelt or $\mathrm{CO}_{2}$ or carbon dioxide, - some of which had to appear somewhere in the text, and all opinion texts were excluded. Imitating other papers [51], media attention was calculated by information space dedicated rather than by the number of pieces of information. Five extension categories of information were established, and a numerical value was adjudicated to each of them, from high to low (see Table 1).

A content analysis $[52,53]$ was applied to the selected sample in order to analyse the following variables: the specific information framings of climate science [25], the general framings [24], their characterization and evaluation, and the degree of recognition of the problem (see Table 2). The Chi-square test was used to determine whether there were statistically significant relationships in framings application in terms of the attention cycle phase, considering that this relationship is significant when the associated probability has a $p$ value $<0.001$ [24].

While Q1 was answered by monitoring the evolution of news coverage, Q2 was addressed through encoding of the content analysis. Next we carried out an in-depth characterization of the three most frequent climate change informative framings in order to answer Q3. Additionally we included a temporal and spatial assessment of the consequences to answer Q4. Finally Q5 was addressed by analysing the specific framings of climate science and measuring the degree of recognition of climate change and the arguments used when the phenomenon was either questioned or denied.

\section{Results and discussion}

Variations in the volume of news coverage (Q1) allowed a clear differentiation of three phases (see Figure 1), which correspond to the three central moments in the cycle model of attention to environmental problems detected by Downs in the U.S. [21]. The first phase ran from 2000 to 2004 and was characterized by small but gradually increasing levels of attention to climate science. In the second phase, from 2005 to 2007, there was an unprecedented explosion of interest in the topic in Spain. This three-year informative climax marked a turning point, from which interest decreased through the end of the decade.

Framings analysis $(\mathrm{Q} 2)$ revealed that $75 \%$ of information on climate science content dealt with consequences of climate change while only $12 \%$ put their emphasis on possible solutions to address this problem. One aspect relevant to its causes only reached $9 \%$ of 
Table 2. List of categories and subcategories of the variables coded in the content analysis: general information framings, specific framings of climate science and recognition of the climate change problem.

\begin{tabular}{|c|c|c|c|c|c|}
\hline \multicolumn{6}{|c|}{ Categories and subcategories of the variables analysed } \\
\hline \multirow[t]{5}{*}{$\begin{array}{l}\text { General } \\
\text { framings }\end{array}$} & Causes & $\begin{array}{l}\text { Natural } \\
\text { Anthropic } \\
\text { Mixed } \\
\text { Unquoted }\end{array}$ & & & \\
\hline & \multirow[t]{2}{*}{ Consequences } & TYPES & ASSESSMENT & $\begin{array}{l}\text { SPATIAL } \\
\text { SCALE }\end{array}$ & $\begin{array}{l}\text { TEMPORAL } \\
\text { SCALE }\end{array}$ \\
\hline & & $\begin{array}{l}\text { More temperature } \\
\text { Less temperature } \\
\text { More rain } \\
\text { Less rain } \\
\text { Sea level rise } \\
\text { Extreme } \\
\text { meteorological } \\
\text { phenomena } \\
\text { Socio-economic } \\
\text { Health of } \\
\text { human beings } \\
\text { Environmental }\end{array}$ & $\begin{array}{l}\text { Positive } \\
\text { Negative } \\
\text { Mixed } \\
\text { Catastrophic } \\
\text { Unknown } \\
\text { No assessment }\end{array}$ & $\begin{array}{l}\text { Local/ re- } \\
\text { gional } \\
\text { National } \\
\text { Global } \\
\text { Other coun- } \\
\text { tries } \\
\text { Unquoted }\end{array}$ & $\begin{array}{l}\text { Currently } \\
\text { Before 2050 } \\
\text { Before 2100 } \\
\text { After 2100 } \\
\text { Unquoted }\end{array}$ \\
\hline & Solutions & $\begin{array}{l}\text { Renewable energies } \\
\text { Energy efficiency } \\
\text { and savings } \\
\text { Emission reduction } \\
\text { policies } \\
\text { Pro nuclear energy } \\
\text { Against nuclear } \\
\text { energy }\end{array}$ & & & \\
\hline & Responsibility & $\begin{array}{l}\text { Mankind } \\
\text { Countries } \\
\text { Industry } \\
\text { Politicians } \\
\text { U.S.A. } \\
\text { Other }\end{array}$ & & & \\
\hline $\begin{array}{l}\text { Specific } \\
\text { framings }\end{array}$ & \multicolumn{5}{|c|}{$\begin{array}{l}\text { Sound science } \\
\text { Not sound science: ambiguous, controversial, polemic. }\end{array}$} \\
\hline \multirow{2}{*}{$\begin{array}{l}\text { Problem } \\
\text { recognition }\end{array}$} & \multicolumn{2}{|c|}{ Negated } & \multicolumn{3}{|c|}{ ARGUMENTS NEGATION/QUESTIONING } \\
\hline & \multicolumn{2}{|l|}{ Questioned } & \multicolumn{3}{|c|}{$\begin{array}{l}\text { Without arguments } \\
\text { Scant scientific information } \\
\text { Economic interests } \\
\text { Ideological stand }\end{array}$} \\
\hline
\end{tabular}

the sample, whereas responsibility stayed at $1 \%$. The analysis of the general framings based on the cycle of attention phases (see Figure 2) showed no statistically significant differences, as the probability associated with Chi-square had a $p$ value $>0.001$.

How did Spanish newspapers construct the causes, consequences and solutions of climate change? As for the causes of the phenomenon (Q3. a), more than half of the sam- 


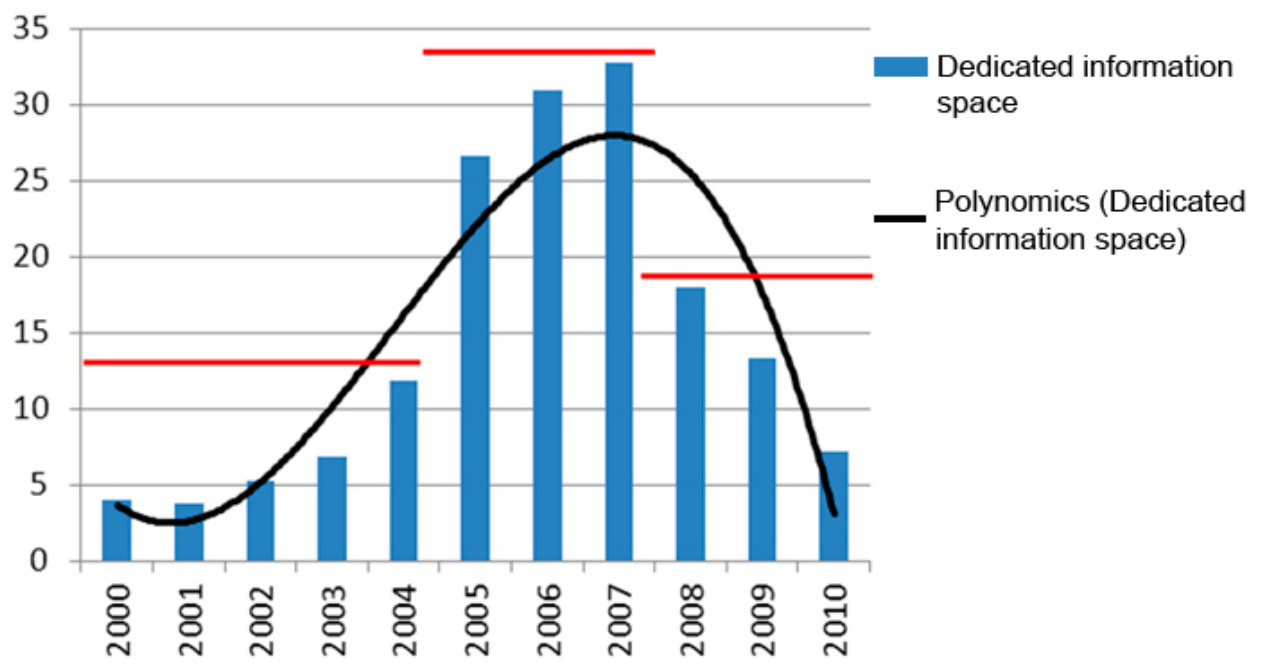

Figure 1. Distribution of media coverage of climate science in the Spanish press over time (2000-2010) with order 3 polynomial trend line and phases of attention cycle to environmental problems (in red): 20002004, 2005-2007, and 2008-2010.

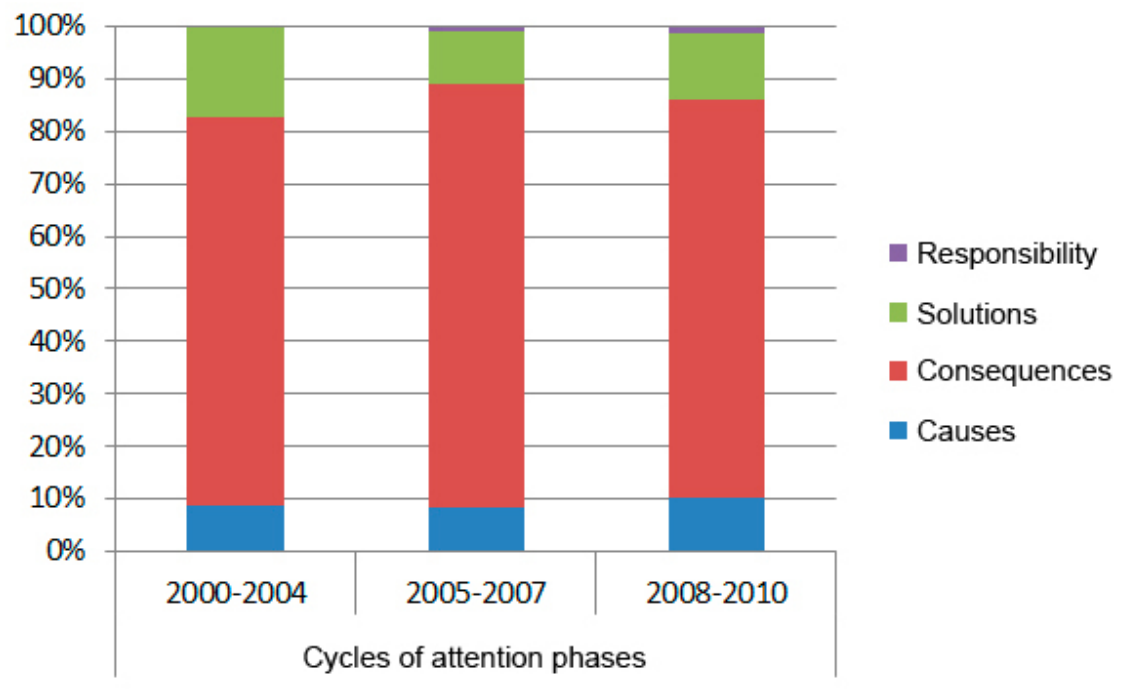

Figure 2. General framings application based on cycles of attention phases. The probability associated with Chi-square has a $p$ value $<0.001$.

ple did not mention them (see Figure 3). $41 \%$ of cases were linked to human activities while only $2 \%$ mentioned natural causes and $6 \%$ identified both natural and anthropogenic causes (mixed causes).

Exploring the consequences (Q3. b) consisted of assessment, characterization and analysis of both spatial and temporal scales. Regarding assessment, $71 \%$ of the cases were rated as either negative (53\%) or catastrophic (18\%). Only $1 \%$ of the sample mentioned positive impacts of the phenomenon and $6 \%$ of the information showed both negative 


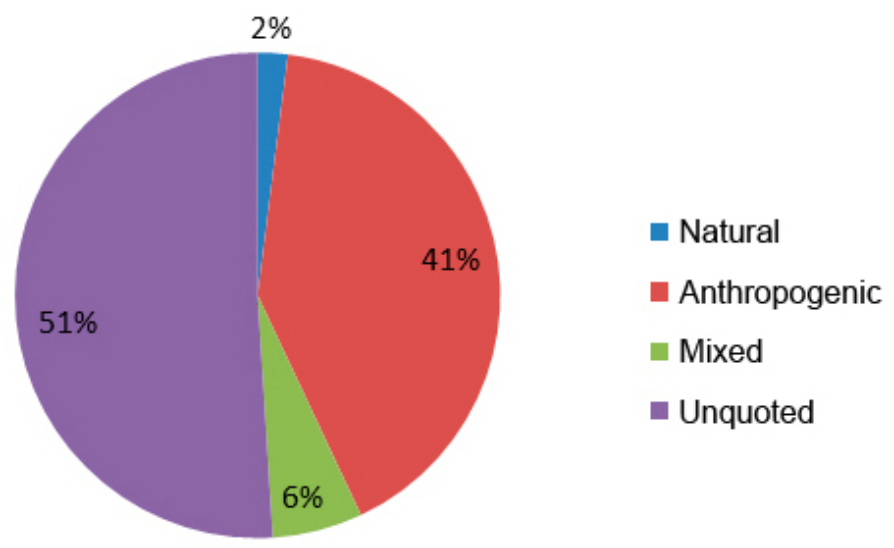

Figure 3. Presence and characterization of the causes of climate change in the Spanish press.

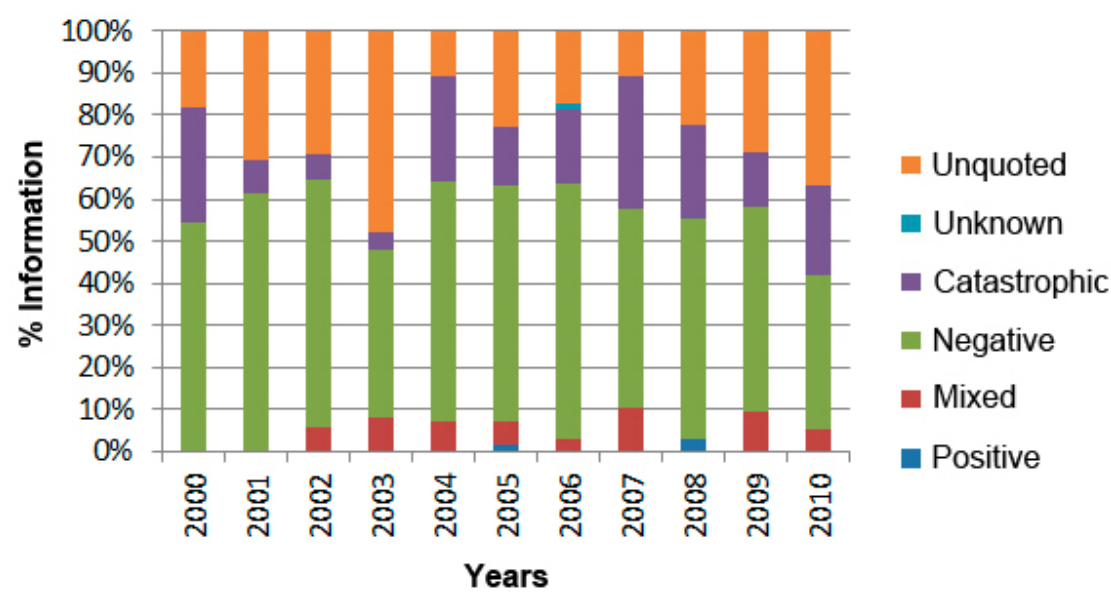

Figure 4. Evolution of the assessment of consequences of climate change in the Spanish press from 2000 to 2010 .

and positive consequences (mixed). From 2007 on, the percentage of cases that assessed consequences decreased longitudinally and both negative and catastrophic evaluations decreased in parallel (see Figure 4).

The characterization of consequences of climate change was a recurring topic in $85 \%$ of the sample (see Figure 5), to the extent that it increased the characterization of causes six fold (see Figure 3). The most quoted result was the rise of temperature (64\%), distantly followed by the occurrence of extreme meteorological events (34\%), sea level rise (27\%), and the environmental consequences affecting the environment and biodiversity (26\%). It is noteworthy that the effects on human health were at seventh place (15\%), behind the socio-economic (23\%), and rainfall decrease consequences (16\%).

Less than half of the sample analysed alluded to climate change solutions (Q3. c) (see Figure 6). 14\% of cases mentioned overall emissions reduction (without elaboration) while renewable energies were quoted in $7 \%$ of the sample and efficiency and energy sav- 


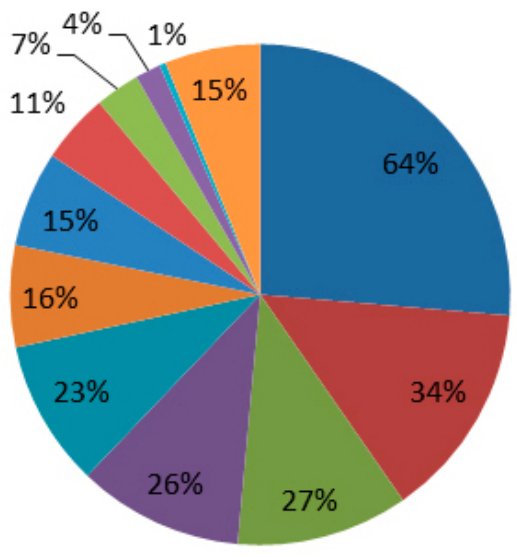

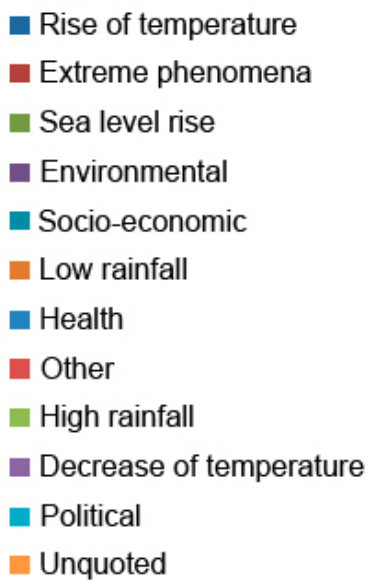

Figure 5. Characterization of the types of consequences of climate change in the Spanish press.

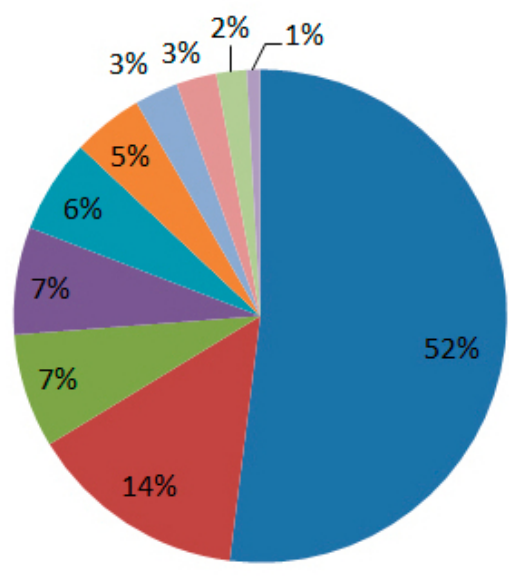

- Unquoted
- Fewer emissions
nenewables
- Adaptation
- Energetic efficiency
- Other
nuclear Yes
Expensive
- Opportunity
- Nuclear No

Figure 6. Characterization of the types of solutions to climate change in the Spanish press.

ings in 6\%. Adaptation measures were contemplated in $6 \%$ of reports. Other subcategory analysis showed that measures to fight climate change are considered expensive by $3 \%$ of the samples, slightly above the percentage presented as a business opportunity (2\%). Finally, the discussion of nuclear energy as a possible alternative to reduce emissions was supported in $3 \%$ of cases and rejected in $1 \%$.

Regarding the spatial horizon (Q4. a) where the Spanish press placed the impacts of climate change, the percentage of information fell as the geographical scope was reduced (see Figure 7). In that sense, while more than $40 \%$ of cases mentioned the consequences of global impact, only $13 \%$ of the sample addressed regional impact and $19 \%$ national impact. In the case of Levante, given its regional character, this difference was smaller although global consequences continued to be higher than regional ones (32\% and 27\%, respectively). However, this trend to spatially distance the consequences of climate change (Q4. b) could not be detected by measuring the time scale. Quite the contrary, our re- 


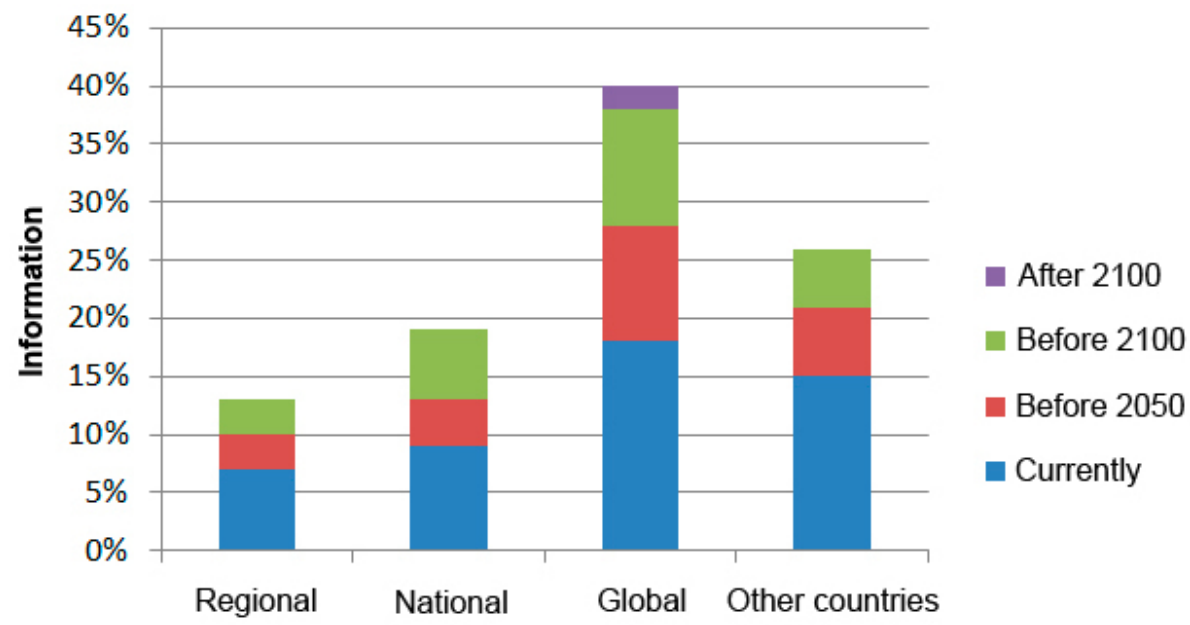

Figure 7. Characterization of spatial and temporal scales of the consequences of climate change in the Spanish press.

search revealed a tie between the percentage of information dealing with climate change impacts that are happening right now and those expected to happen in the medium and long term. According to these findings, the hypothesis of environmental hyperopia in the Spanish press was only confirmed in relation to its spatial scale but it did not occur in the time scale.

The analysis of specific framings of climate science (Q5) revealed that $13 \%$ of the sample was characterized by highlighted controversy, polemic and uncertainty compared to $87 \%$ which presented this branch of knowledge as sound science. Regarding recognition of climate change as a real problem that must be addressed, $9 \%$ of the reports questioned or denied such an approach. This percentage was screened further to try to explain the reasons for that position. It was found that in 30\% of cases questioning or denial were advanced without any arguments at all (see Figure 8 ) while in $55 \%$ of cases, it was argued that further investigation was needed due to both limited scientific information or scientific errors (12\%). Longitudinally it was found that during the last two years of the period analysed (2009 and 2010), more than 30\% of the published reports showed sceptical positions or sourced from climate change deniers, coinciding with the collapse of negotiations on reducing emissions in Copenhagen and with several scandals in which climate scientists and even the IPCC - i.e. Climategate - were involved.

\section{Conclusion}

Spanish press interest in climate science from 2000 to 2010 was in line with the central phases of the attention cycle to environmental problems [21]. This pattern consisted of a period of gradual increase of attention (2000-2004), three years of a record-breaking information climax (2005-2007), and a steep decline (2008-2010). This cyclical pattern replicated the one obtained by analysing the coverage of climate change in the U.S., from 


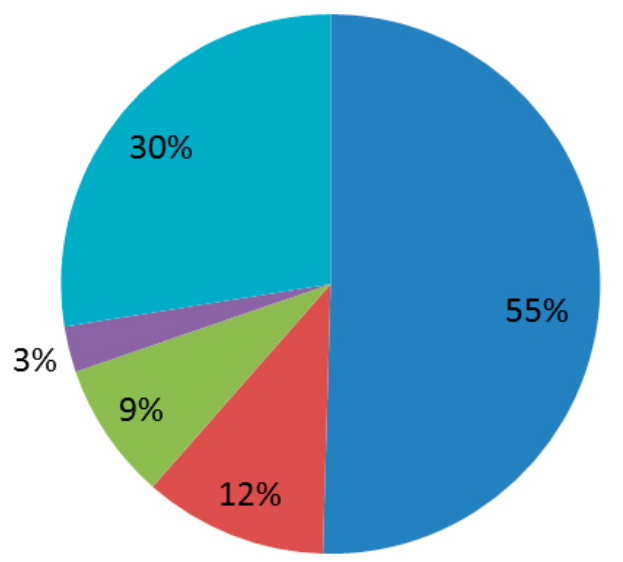

Scant information

Scientific errors

Economic interests

Ideological position

No arguments

Figure 8. Arguments used to either question or deny the existence of climate change in media coverage of climate science from the Spanish press.

1985 to 1994 [24] and from 1980 to 1995 [23]. Comparing the 2000-2006 Spanish sample to other English-language news from numerous countries ${ }^{4}$ spanning the same period [54], the pattern of media attention was equally robust in presenting the same upward trend.

Fifty per cent of information on climate science published in Spain from 2000 to 2010 was concentrated during the 2005-2007 period. This pattern of media attention showed permeability to two factors: the overlapping of numerous events related to climate change that took place during those years and the emergence of other social problems, economic in nature, with which it had to share space [55]. Concerning the overlapping of events in scientific spheres, the fourth IPCC assessment report was presented in 2007, as well as other reports by Spanish universities assessing the impact of climate change at national and regional levels [56-58]. Politically, a Commission for the Coordination of Climate Change Policies between Spain's Central Administration and Autonomous Communities was created, and national allocation plans for emission rights and climate change adaptation were approved. Finally, in 2007 the documentary "An Inconvenient Truth" by Al Gore premiered in Spain, with Gore receiving the Prince of Asturias Award for International Cooperation and sharing the Nobel Peace Prize with the IPCC that same year.

Unlike in the U.S. press, where the consequences of climate change (both as a framing and as news narrative element) were more present during the phase of increased media attention, in Spain the highest interest in the consequences occurred both during the three years of maximum coverage and the phases of increase and decrease. Compared to other studies [23, 24], the excessive interest of Spanish newspapers in highlighting the consequences of climate change, regardless of the attention cycle moment [21], may be due to the high vulnerability of Spanish territory to the consequences of climate change, due to its geographic location [56]. However, in assessing these differences, methodological differences between the studies compared must be taken into account, starting with

\footnotetext{
${ }^{4}$ Australia, Canada, Hong Kong, Irland, Israel, Japan, South Korea, Netherlands, New Zealand, Russia, South Africa, Thailand, U.K. and U.S.
} 
the different time frame. In addition, samples by Trumbo [24], McComas and Shanahan $[23,59]$ focused on climate change while the Spanish newspapers sample had a more specific focus, climate science. However, the Spanish newspapers trend coincided with the one detected by opinion polls: $32 \%$ of Spaniards considered themselves informed about the consequences of climate change compared to only $2 \%$ who considered themselves informed about its solutions [59].

As for the types of causes of climate change in the Spanish press, $41 \%$ of cases mentioned an exclusively anthropogenic origin of the phenomenon compared with only $6 \%$ of cases in the American press [47]. Another important difference between the two countries is that while only $6 \%$ of the sample mentioned a combination of natural and anthropogenic causes in Spain, that figure exceeded 30\% in the US. These differences may be due to activities by American lobby groups to promote denial of climate change in order to create scientific uncertainty about the problem [60-63], both within the US and abroad. Opinion polls in the US showed that $39 \%$ of people said that there was little or no scientific consensus on climate change [64, 65], while in Spain, this figure was slightly lower (31\%) [59], although it could be considered unusually high if we take into account that in this European country there are no powerful lobby groups like those in the US. Indeed, the analysis of specific framings showed that only $13 \%$ of Spanish newspaper reports offered framings of climate science as science that was not sound ("bad science"), compared to $34 \%$ of American press reports [25]. In 9\% of the analysed sample, Spanish newspapers may also have created scientific uncertainty by denying or questioning the existence of climate change, stressing scientific errors and the shortage of scientific information available. The average percentage of the entire sample was outweighed by the financial daily Expansión (29\%) and by El Mundo (17\%). Not surprisingly, Expansión targets the Spanish business elite.

The vast majority of climate change impacts were rated as negative and catastrophic over the decade, although this percentage diminished as media attention started to decline from 2008 onward. An analysis of taxonomy of consequences showed that rise of temperature appeared in six out of ten pieces of reporting, nearly doubling the occurrence of extreme weather events. Thirdly, rising sea levels were treated in $27 \%$ of cases. Contrary to what it might have been expected, Levante, a newspaper edited in the Eastern coastal city of Valencia, paid less attention than other Madrid newspapers to rising temperatures and placed rising sea levels in fourth place while in Madrid, sea level rise was in third place.

The hypothesis of environmental hyperopia [20] in the Spanish press was confirmed in relation to its spatial scale but it did not occur in the time scale. Environmental hyperopia consists of perceiving environmental problems as more serious the further away they are - both in time and space — as a strategy to reduce our responsibility in creating the phenomenon and in designing response measures. When comparing these findings in Spanish newspaper coverage with opinion polls in Spain [66], we found that residents of the Spanish Mediterranean coastal areas considered climate change to be a current $(60 \%)$ rather than a future problem $(30 \%)$, although $74 \%$ of the total sample stated future generations would be most affected by the consequences of climate change. 
Ultimately, this research has identified a certain number of deficiencies in climate science coverage in the Spanish press during the first decade of the 21st century, when the issue reached its peak of notoriety both in media [33, 38, 49, 67-69] and public opinion $[17,59,66,70-73]$. Among other shortcomings, an excessive interest in the consequences of climate change, the permeability of media attention to overlapping events related to the phenomenon, and the appearance and evolution of other problems, as well as the creation of scientific uncertainty were stressed.

In the context of improving climate science communication, we argue that these deficiencies are problematic in addressing climate change. In this regard, media coverage focused on the consequences of climate change can be more appealing to an audience, but can also cause impotence if the problem is of such dimension that one feels unable to cope with it. Similarly, the permeability of the volume of media attention to overlapping events means that media interest in climate science coverage dramatically increased when several related events occurred in a short period of time - for example, the news coverage record reached from 2005 to 2007 with the launch of the $4^{\text {th }}$ IPCC assessment report and other national and regional impact reports published by Spanish universities and government institutions [56-58]. However, this flow of information also decreased when other social problems came into scene - as occurred from 2008 with the irruption of the economic crisis in Spain. In the context of science communication, this pattern represents a limitation on the flow of information from the scientific sphere to the public arena.

Finally, the creation of scientific uncertainty about climate change is also problematic when it is used as an excuse to delay decision-making repeating the mantra "more research is needed". The current status quo greatly favors those social agents who benefit from the absence of a mandatory global regulation on reducing emissions of greenhouse gases. Furthermore, it represents a threat to the inhabitants of the geographical areas most vulnerable to the consequences of climate change, which also tend to be underdeveloped or developing countries. Assuming coverage of climate science can act either as a facilitator or as an inhibitor of individual action and policy decision-making, future improvement of reporting on this issue can only be reached through analytical knowledge of such journalistic shortcomings.

\section{References}

[1] IPCC (2007), Contribution of Working Groups I, II and III to the Fourth Assessment Report of the Intergovernmental Panel on Climate Change. Synthesis Report, available from: http://www.ipcc.ch/publications_and_data/ar4/syr/en/contents.html, accessed on March 2009.

[2] M.T. Boykoff (2007), "Flogging a dead norm? Newspaper coverage of anthropogenic climate change in the United States and United Kingdom from 2003 to 2006", Area 39: 470-481.

[3] A. Carvalho (2005), "Representing the politics of the greenhouse effect: discursive strategies in the British media", Critical Discourse Studies 2(1): 1-29.

[4] A. Carvalho and J. Burgess (2005), "Cultural circuits of climate change in U.K. broadsheet newspapers, 1985-2003”, Risk Analysis 25(6): 1457-1469. 
[5] A. Carvalho and E. Pereira (2008), "Communicating climate change in Portugal: a critical analysis of journalism and beyond", in Communicating climate change: discourses, mediations and perceptions, A. Carvalho ed., Centro de Estudos de Comunicaçao e Sociedade, Universidad de Minho, Braga, Portugal, pgg. 126-156.

[6] S.C. Aykut, J.B. Comby and H. Guillemot (2012), "Climate change controversies in french mass media 1990-2010”, Journalism Studies 13(2): 157-174.

[7] D. Brossard, J. Shanahan and K. McComas (2004), "Are issue-cycles culturally constructed? A comparison of French and American coverage of global climate change", Mass Commun. Soc. 7(3): 359-377.

[8] H.P. Peters and H. Heinrichs (2009), "El cambio climático en los medios alemanes", Infoamérica-ICR 1: 59-78.

[9] P. Weingart, A. Engels and P. Pansegrau (2000), "Risks of communication: discourses on climate change in science, politics, and the mass media", Pub. Underst. Sci. 9(3): 261-283.

[10] L. González Alcaraz (2010), "Este asunto no es nuestro. El cambio climático en la prensa escrita de referencia argentina”, KAIROS 26: 1-17.

[11] C. Rosen and J. Cruz-Mena (2008), "Climate change and the daily press: did we miss the point entirely?", in Communicating climate change: discourses, mediations and perceptions, A. Carvalho ed., Centro de Estudos de Comunicaçao e Sociedade, Universidad de Minho, Braga, Portugal, pgg. 110-125.

[12] C. Rosen (2008), Análisis de la cobertura periodística del cambio climático en 2001 desde un modelo de funcionalidad. El periodismo de ciencia en la prensa escrita nacional y extranjera, Thesis, Facultad de Ciencias Políticas y Sociales, Universidad Nacional Autónoma de México, México, D.F., p. 191.

[13] B. Takahashi (2011), "Framing and sources: a study of mass media coverage of climate change in Perú during the V ALCUE”, Pub. Underst. Sci. 20(4): 543-557.

[14] J.L. Piñuel-Raigada et al. (2012), "Comunicación, controversias e incertidumbres frente al consenso científico acerca del cambio climático", Cuadernos Artesanos de Latina 30, Sociedad Latina de Comunicación Social - edición no venal - La Laguna (Tenerife), 2012 - Creative Commons.

[15] C. Polino, M.A. Fazio and L. Vaccarezza (2003), "Medir la percepción publica de la ciencia en los países iberoamericanos. Aproximación a problemas conceptuales”, Revista Iberoamericana $C T S+I 5$.

[16] K.M. Wilson (1995), "Mass media as sources of global warming knowledge", Mass Communications Review 22: 75-89.

[17] P.A. Meira (2008), Comunicar el cambio climático. Escenario social y líneas de actuación, Series Educación Ambiental, Ministerio de Medio Ambiente y Medio Rural y Marino - Organismo Autónomo de Parques Nacionales, Madrid, Spain.

[18] IPCC (2004), 16 years of scientific assessment in support of the climate convention, available from: http://www.ipcc.ch, accessed on March 2009.

[19] K.R. Stamm, F. Clark and P. Reynolds Eblacas (2000), "Mass communication and public understanding of environmental problems: the case of global warming", Pub. Underst. Sci. 9: 219-237.

[20] D.L. Uzzel (2000), “The Psycho-spatial dimension of global environmental problems”, J. Environ. Psychol. 20: $307-318$.

[21] A. Downs (1972), "Up and down with ecology: the 'issue-attention cycle"', Public Interest 28: 38-50.

[22] R. Entman (1993), "Framing: toward clarification of a fractured paradigm", J. Commun. 43(4): 51-58. 
[23] K. McComas and J. Shanahan (1999), Telling stories about global climate change - Measuring the impact of narratives on issue cycles, Commun. Res. 26(1): 30-57.

[24] C. Trumbo (1996), "Constructing climate change: claims and frames in US news coverage of an environmental issue”, Pub. Underst. Sci. 5: 269-283.

[25] L. Antilla (2005), "Climate of scepticism: US newspaper coverage of the science of climate change", Global Environ. Chang. 15(4): 338-352.

[26] M. McCombs and D. Evatt (1995), "Issues and attributes: Exploring a new dimension in agenda setting”, Comunicación y Sociedad 8(1): 7-32.

[27] R. Reig and J.L. Alcaide (2007), "El calentamiento de la prensa ante el cambio climático. El caso Al Gore y la tendencia al catastrofismo”, in Cultura Verde. Ecología, Cultura y Comunicación, Consejería de Medio Ambiente, Junta de Andalucía, pgg. 303-325.

[28] M. Alcíbar Cuello (2007), “Ciencia, política y comunicación. Una aproximación a la construcción social del cambio climático en An inconvenient truth", in Cultura Verde. Ecología, Cultura y Comunicación, Consejería de Medio Ambiente, Junta de Andalucía, pgg. 261-282.

[29] P. Pedraza (2007), "Paisajes desolados (el cambio climático y el cine)", Saitabi: revista de la Facultat de Geografia i Història de la Universidad de Valencia 57: 227-240.

[30] T.D. Lowe (2006), Is this climate porn? How does climate change communication affect our perceptions and behaviour?, Tyndall Centre for Climate Change Research, University of East Anglia, Norwich, U.K., pg. 37.

[31] T.D. Lowe et al. (2006), "Does tomorrow ever come? Disaster narrative and public perceptions of climate change", Pub. Underst. Sci. 15: 435-457.

[32] A. Brown (2006) "La "imparable” catástrofe climática”, El Mundo, January 9, pg. 26.

[33] R. Fernández Reyes (2009), El cambio climático en editoriales de prensa. Ecología política y periodismo ambiental: propuesta de herramienta de análisis, Ph.D. Thesis, Departamento de Geografía, Historia y Filosofía, Universidad Pablo de Olavide, Sevilla, Spain.

[34] J.B. Corbett et al. (2009), Comunicación y cambio climático, Cátedra UNESCO de Comunicación, Universidad de Málaga, Málaga, Spain, pg. 192.

[35] M. Djerf-Pierre (2013), "Green metacycles of attention: Reassessing the attention cycles of environmental news reporting 1961-2010”, Pub. Underst. Sci. 22(4): 495.

[36] E. Goffman (2006), Frame analysis. Los marcos de la experiencia, Centro de Investigaciones Sociolgicas (CIS).

[37] R. Entman (2004), Projections of power: framing news, public opinion and US foreign policy, University of Chicago Press, Chicago, U.S.A.

[38] S. Parrat Fernández (2009), “Climate change in Spain’s media. A deficient answer”, Infoamerica-ICR 1: 129-138.

[39] J.C. Gordon, T. Deines and J. Havice (2010), "Global warming in the media: Trends in a Mexico city newspaper”, Sci. Commun. 32(2): 143-170.

[40] R. Entman (2007), "Framing bias: media in the distribution of power", J. Commun. 57(1): 163-173.

[41] K. Bickerstaff et al. (2008), "Reframing nuclear power in the U.K. energy debate: nuclear power, climate change mitigation and radioactive waste", Pub. Underst. Sci. 17: 145-169.

[42] T.A. Morton et al. (2011), "The future that may (or may not) come: How framing changes responses to uncertainty in climate change communications", Global Environ. Chang. 21(1): 103-109.

[43] D.B. Sachsman, J. Simon and J. Myer Valenti (2004), "Risk and the environment reporters: a four-region analysis", Pub. Underst. Sci. 13: 399-416.

[44] T. Takeshita (2006), "Current critical problems in agenda-setting research", Int. J. Public. Opin. R. 18(3): 275-296. 
[45] N. Smith and H. Joffe (2012), "How the public engages with global warming: A social representations approach", Pub. Underst. Sci. 1st June.

[46] Oficina de Justificación de la Difusión (2012), Control de diarios impresos, available from: http://www.ojd.es/OJD/Portal/diarios_ojd/_4DOSpuiQo1Y_FOivPcLIIA, accessed on 3 Jan 2012.

[47] M.T. Boykoff and J.M. Boykoff (2004), "Balance as bias: global warming and the US prestige press", Global Environ. Chang (14): 125-136.

[48] A. Dirikx and D. Gelders (2008), "Newspaper communication on global warming: different approaches in the US and the EU?", in Communicating climate change: discourses, mediations and perceptions, A. Carvalho ed., Centro de Estudos de comunicaçao e Sociedade, Universidad de Minho, Braga, Portugal, pgg. 98-109.

[49] C.M. Duarte et al. (2009), Cambio global. Impacto de la actividad humana sobre el sistema Tierra, Colección Divulgación, CSIC y Catarata, Madrid, Spain.

[50] E. Lopera (2009), "El cambio climático como casuística de la construcción mediática de los problemas medioambientales", Informes Técnicos Ciemat 1167, Madrid, Spain.

[51] M. Escribano and M.A. Quintanilla (2005), "La biotecnología y los medios de comunicación en España”, Revista CTS 2(4): 21-39.

[52] K. Krippendorff (1990), Metodología del análisis de contenido: teoría y práctica, Ediciones Paidós, Barcelona, Spain.

[53] D. Riffe, S. Lacy and F. Fico (2005), Analyzing media messages using quantitative content analysis in research, LEA's communication series, Lawrence Erlbaum Associates, Mahwah, N.J., U.S.A.

[54] M.T. Boykoff and J.T. Roberts (2007), "Media coverage of climate change: current trends, strengths, weaknesses", Human Development Report 2007/2008, Fighting climate change: Human solidarity in divided world, Occasional Paper, 2007/3.

[55] S. Hilgartner and C.L. Bosk (1988), "The rise and fall of social problems: a public arenas model”, Am. J. Sociol. 94(1): 53-78.

[56] J.M. Moreno et al. (2005), Evaluación preliminar de los impactos en España por efecto del cambio climático, Ministerio de Medio Ambiente, Spain.

[57] J.C. Abanades et al. (2007), El cambio climático en España. Estado de la situación, Ministerio de Medio Ambiente, Spain.

[58] F. Méndez et al. (2004), "Estudio de los impactos en la costa española por efecto del cambio climático", in El clima entre el mar y la montaña, J. García Codron et al. eds., Asociación Española de Climatología y Universidad de Cantabria, Santander, pgg. 63-72.

[59] P.A. Meira et al. (2011), La sociedad ante el cambio climático. Conocimientos, valoraciones y comportamientos en la población española 2011, Fundación Mapfre.

[60] M.T. Boykoff and J.M. Boykoff (2007), "Climate change and journalistic norms: A case-study of US mass-media coverage”, Geoforum 38: 1190-1204.

[61] P. Michaels (1995), “Top 10 global warming myths”, World Climate Report 1(5).

[62] R.A. Muller (2012), "The conversion of a climate-change skeptic", The New York Times, July 28, available from: http://www.nytimes.com/2012/07/30/opinion/the-conversion-of-a-climate-changeskeptic.html?pagewanted=all, accessed on December 2012.

[63] A. Robinson (2010), "Los lobbies energéticos financian el negacionismo climático. Se trata de restar apoyos a las leyes de Obama para reducir emisiones", lavanguardia.com, November 1, available from: http://www.lavanguardia.com/internacional/20101101/54063261114/los-lobbies-energeticosfinancian-el-negacionismo-climatico.html, accessed on April 2013. 
[64] A. Leiserowitz, N. Smith and J.R. Marlon (2010), Americans' Knowledge of Climate Change. Yale Project on Climate Change Communication, available from: http://environment.yale.edu/climate/ files/Climate-ChangeKnowledge2010.pdf, accessed on April 2013.

[65] A.A. Leiserowitz et al. (2010), "Climategate, public opinion, and the loss of trust", in Working Paper Series, School of Forestry and Environmental Studies, Yale University, New Haven, CT., U.S.A.

[66] P.A. Meira, M. Arto and P. Montero (2009), La sociedad ante el cambio climático. Conocimientos, valoraciones y comportamientos en la población española, Fundación Mapfre.

[67] B. Díaz Nosty (2009), "Communication solutions for sustainable innovation. Building climate change in the media”, Infoamérica-ICR 1: 91-115.

[68] R. Fernández Reyes (2010), Irrupción mediática y representación ideológica del cambio climático en España. Contribuciones a las Ciencias Sociales, available from: http://www.eumed.net/rev/ cccss/10/rfr.htm, accessed on March 2013.

[69] R. Fernández Reyes (2010), Reconocimiento y cuestionamiento mediático del cambio climático en España. Contribución a las Ciencias Sociales, available from: http://www.eumed.net/rev/cccss/ 10/rfr2.htm, accessed on March 2013.

[70] Departamento de Estudios Sociales de la Fundación BBVA (2008), Percepciones y actitudes de los españoles hacia el calentamiento global, Fundación BBVA, Madrid, Spain.

[71] Departamento de Estudios Sociales de la Fundación BBVA (2006), Conciencia y conducta medioambiental en España, Fundación BBVA, Madrid, Spain.

[72] Comisión Europea (2008), Eurobarómetro especial N. 300. Europeans' attitudes towards climate change, Comisión Europea, Bruselas, Belgium.

[73] Comisión Europea (2009), Eurobarómetro especial N. 322. Europeans' attitudes towards climate change, Comisión Europea, Bruselas, Belgium.

\section{Authors}

Emilia Lopera holds a researcher position in the Research Unit on Scientific Culture at CIEMAT, Spain. She obtained a Ph.D. in Communication at the Universidad de Valencia, Spain. Her research interests include environmental risk communication, communication of science, and public perception about environmental risks, policy and media agenda building on environmental issues. E-mail: emilia.lopera@ciemat.es.

Carolina Moreno is Full Professor of Journalism in the Department of Theory of Language and Communication at the University of Valencia, Spain, and a member of the Research Unit on Scientific Culture of CIEMAT. She is a professor of science communication and her research focuses on content analysis of media reports related to science and technology. E-mail: carolina.moreno@uv.es.

How TO CITE: E. Lopera and C. Moreno, The uncertainties of climate change in Spanish daily newspapers: content analysis of press coverage from 2000 to 2010, JCOM 13(01)(2014)A02. 